\title{
Thoughts on the Names of the Thirty(-six) Rime Table Initials
}

\author{
W. South Coblin \\ University of Iowa \\ south-coblin@uiowa.edu
}

\begin{abstract}
Closely associated with the Chinese rime table (Chin. děngyùntú 等韻圖) tradition is an ordered list of syllables, referred to in Chinese as the Sānshíliù zìmŭ 三十六字母. As this term indicates, there are thirty-six members in the usually cited full list. A shorter version, found in the so-called Shǒuwēn 守溫 Fragments from Dunhuang, has only thirty members (cf. Coblin 2006a). In addition to the copies of the list incorporated into the various tables themselves, several "disembodied" lists, perhaps copybook exercises of some sort, have also been found in the broader corpus of Chinese Dunhuang texts (Coblin 2006b: 146). The syllable initial classes for which the characters in the rime tables serve as names are basic componential elements in the field of traditional Chinese historical phonology and as such have been subject to intense scrutiny for nearly 1000 years. On the other hand, the actual names themselves have attracted little attention. It has been noted that each naming syllable denoted by the characters in the list embodies the particular medieval syllable initial of the sound class for which it stands in the tables. But beyond this the question of how these particular syllables, rather than all other available ones, were selected, seems to have aroused scant interest among philologists and sinolinguists. It is, accordingly, this question that will be the topic of the present paper.
\end{abstract}

\section{Keywords}

Rime Tables - Rime Books - Chinese philological tradition - historical phonology

We shall begin by outlining the background of the problem. The oldest attested Chinese rime tables are the sister texts, Yùnjing 韻鏡 (YJ) and Qìyinlüè 七音略 (QYL). Both first appeared in print in the twelfth century (Coblin 2006a, 2006b) and apparently descend from the same ancestral prototype. This, in turn, is widely thought to derive from even earlier rime tables, but how old these primeval works may have been, or what their ultimate origin was, is uncertain. Because the YJ and the QYL incorporated into their

1 Throughout this paper the names of two of the thirty-six initials, i.e., 溪 qī and 禪 shàn, are advisedly so transcribed. This is how the present writer's traditionally educated Chinese teachers read these forms in the mid-196o's and also the way they were pronounced in the classes of my magister primus, Professor F.K. Li. Here, as in all things, I follow, and shall always follow, the best available received traditions. 
structural nomenclature certain terms from the now lost Qièyùn 切韻 (6o1 A.D.) and its progeny, down to the still extant Guăngyùn 廣韻 (GY; 1008 A.D.), it is assumed that the rime tables must be related in some fairly direct way to the QY lineage of texts.

The 36 and 30-member initial lists are arranged first according to points, and then to manners, of articulation, in a configuration that is reminiscent of the sequence of obstruent letters in alphabets of the Indic grammatical tradition. A general and widely accepted assumption is therefore that the structure of the rime tables reflects Indic influence, perhaps in concert with the importation of Buddhism into China. The exact process of this borrowing is not known, but it is nonetheless possible to hazard certain guesses about it. First of all, it seems likely that the basic idea of using Chinese characters to represent particular ordered sets of sounds derives from the devanāgari-style alphabetic syllable sets used for the precise transcription of Indic terms in Chinese texts. ${ }^{2}$ The closely related Chinese Siddham script tradition is also thought to have played a role in the basic conceptualizations reflected in the rime tables. What is noteworthy for us, however, is that the Chinese did not simply adapt the already available Indicbased transcriptional alphabets for use in their clearly Siddham-like rime tables. Why is this so? Why did the table-makers bypass these ready-made Indic lists and make a new one using entirely different characters? And, how did they decide which new characters to use in the new list?

The answer to the first question may be that the framers of the rime table list wished to divorce their new alphabetic series from the patently religious ones found in Buddhist texts and instead formulate a purely secular construct. If this conclusion is valid, then it brings us at last to the central issue we wish to address here i.e., how did they accomplish their task?

\section{$2 \quad$ Some Possibilities}

We shall now consider a number of possible scenarios for the compilation process, beginning with what in our view are the least likely ones and then moving to those that seem more promising.

The first possibility is that the selection of characters in the lists was totally arbitrary, i.e., they were chosen in some entirely random fashion and reflect no particular selection criteria whatsoever. If this were so, then any search for such criteria should turn up no patterning of any sort in the lists. As we shall see below, this is not the case.

A second possibility is that the characters were deliberately chosen from some literary, philosophical, or other such source. This might have been done for the mnemonic value of the said source in identifying the members of the list, or even simply for the amusement of the list-maker. One thinks, for example, of the famous Zǎoméish $̄$ 早梅詩 of Lán Mào 蘭茂 (1397-1476), which encapsulates in its twenty syllables the twenty initials of the Yünlüe yitōng 韻略易通 (published 1442). In connection with this possibility, our computer scans of searchable texts has not so far unearthed a likely candidate for such a source.

Far more promising for us is the fact that nearly $80 \%$ of the graphs in the lists occur as first or head characters in the homophone groups of the QY and its derivatives. This is illustrated in the tabulation below. For each rime table initial we give its written Chinese and romanized forms. Entries for characters occurring only in the Shǒuwēn initial list are prefixed with the letters "sw." Those occurring only in the longer Yùnjing version and not in the Shǒuwēn list are prefixed with "YJ." List characters that do not occur as head characters in their respective GY homophone groups are prefixed with a double star. Added notes for certain items give information regarding differences between the received GY text and the

2 Neat summaries of these transcriptional alphabets can be found in Luo (1963), tables following p. 64. 
surviving QY manuscript and fragments. The primary manuscript version in question is that of the Wáng Rénxū Qièyùn (wrx; Long [1968]). The fragments are cited after Shíyùn huibiān 十韻彙編 (Liu 1968). ${ }^{3}$ Numerals are page numbers, regarding which see anon.

YJ 幫 bāng. 185 .

SW 不 bù. 210.

YJ 滂 pāng 184.

sw 芳 fāng 180.

並 bìng 322 .

明 míng 188 .

YJ **非 fēi 66 .

YJ 敷 fū 80 .

$\mathrm{YJ}$ 奉 fèng. 240.

YJ 微 wéi 65 .

端 duān 126.

透 tòu 441

定 dìng 434

泥 ní 93 .

知 zhī 51 .

**徹 chè 501,502 .

**澄 chéng 188, 200. The form on p. 200

serves as head character in wRX.

YJ 娘 niáng 178

見 jiàn 409

溪 qī 93.

群 qún 113 .
疑 yí 61 .

精 jīng 192.

清 qīng 192.

從 cóng 38 .

心 xīn 38 .

邪 xié 170 .

照 zhào 415 .

穿 chuān 142.

YJ 牀 chuáng 178

**審 shěn 331 .

**禪 shàn 411. In this reading, the graph is not present in WRX but does appear in various QY fragments, where it is not at the head of its homophone group.

影 y̌rng 318 .

**曉 xiău 298.

**匣 xiá 546 .

喻 yù 367 .

來 lái 101.

rì 470.

In this list, each numeral following an entry represents a page number in Zhōu Zǔmó's 196o edition of the GY. These are the pages in this text where the homophone groups containing the pertinent characters occur. Although these numbers may of course be useful to readers who have access to this particular GY edition, that is not our purpose in giving them here. Instead, they are cited in order to indicate how the respective entries are distributed within the body of the QY/GY text as a whole, which in this edition has altogether 563 pages. Examining these numbers, we see that the characters in question are scattered disparately throughout the book. If their use as initial category names was based on selection directly from the homophone groups in these texts, then the choice must have been essentially random within the body of the work as a whole.

There is, however, a further possibility which needs to be considered. It is also worth noting that nearly $90 \%$ the characters in the rime table initial list also agree with token graphs found in the individual cells of the YJ and QYL tables. In a sense, this is not all that surprising, for we know that a high percentage of

3 On the various manuscripts and text versions in question here, see Bottéro (2013). 
these rime table token graphs are in fact homophone group head characters in the QY lineage of dictionaries. However, the matter is interesting enough that we shall now pursue it further. In the following table we present again our list of rime table initial characters; but this time the information given is somewhat different. For here we supply for each initial name the number of the YJ table in which it occurs, followed by the designation of the table as nèizhuăn 內轉 $(\mathrm{N})$ “inner turning” or wàizhuăn 外轉 $(\mathrm{W})$ “outer turning." Names that do not occur as YJ token characters are followed by a long dash, after which we place in parentheses the number and nèi/wài designation of the table in which the initial name would have occurred if it had been used as a token.

$\begin{array}{ll}\text { 幫 } 31 \mathrm{~N} & \text { 群 } 20 \mathrm{~W} \\ \text { 不 } 37 \mathrm{~N} & \text { 疑 } 8 \mathrm{~N} \\ \text { 滂 } 31 \mathrm{~N} & \text { 精 } 33 \mathrm{~W} \\ \text { 芳 } 31 \mathrm{~N} & \text { 清 } 33 \mathrm{~W} \\ \text { 並 } 35 \mathrm{~W} & \text { 從 } 2 \mathrm{~N} \\ \text { 明 } 33 \mathrm{~W} & \text { 心 } 38 \mathrm{~N} \\ \text { 非 } 10 \mathrm{~N} & \text { 邪 } 29 \mathrm{~N} \\ \text { 敷 } 12 \mathrm{~N} & \text { 照 } 25 \mathrm{~W} \\ \text { 奉 } 2 \mathrm{~N} & \text { 穿 } 24 \mathrm{~W} \\ \text { 微 } 10 \mathrm{~N} & \text { 牀 } 31 \mathrm{~N} \\ \text { 端 } 24 \mathrm{~W} & \text { 審一 }(38 \mathrm{~N}) \\ \text { 透 } 37 \mathrm{~N} & \text { 禪一 }(23 \mathrm{~W}) \\ \text { 定 } 35 \mathrm{~W} & \text { 影 } 33 \mathrm{~W} \\ \text { 泥 } 13 \mathrm{~W} & \text { 曉 } 25 \mathrm{~W} \\ \text { 知 } 4 \mathrm{~N} & \text { 匣一 }(40 \mathrm{~W}) \\ \text { 徹 } 23 \mathrm{~W} & \text { 喻一 }(11 \mathrm{~N}) \\ \text { 澄 } 42 \mathrm{~N} & \text { 來 } 13 \mathrm{~W} \\ \text { 娘 } 31 \mathrm{~N} & \text { 日 } 17 \mathrm{~W} \\ \text { 見 } 23 \mathrm{~W} & \\ \text { 溪 } 13 \mathrm{~W} & \end{array}$

From this list we see that four out of our 38 characters do not occur in the YJ cells, the same also being true for the QYL. But is there any detectable patterning in the selection of token characters? Let us begin by re-sorting the list according to the table numbers of the cell tokens. Characters that do not occur as tokens are first added at the head of the tabulation and then sorted again into the body of it.

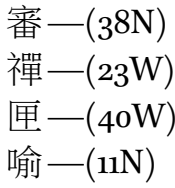

奉 $2 \mathrm{~N}$

從 $2 \mathrm{~N}$

知 $4 \mathrm{~N}$ 
疑 $8 \mathrm{~N}$

非 $10 \mathrm{~N}$

微 $10 \mathrm{~N}$

喻一 $(11 \mathrm{~N})$

敷 $12 \mathrm{~N}$

泥 $13 \mathrm{~W}$

溪 $13 \mathrm{~W}$

來 $13 \mathrm{~W}$

日 $17 \mathrm{~W}$

群 $20 \mathrm{~W}$

徹 $23 \mathrm{~W}$

見 $23 \mathrm{~W}$

禪一 $(23 \mathrm{~W})$

端 $24 \mathrm{~W}$

穿 24 W

照 $25 \mathrm{~W}$

曉 $25 \mathrm{~W}$

邪 $29 \mathrm{~N}$

幫 $31 \mathrm{~N}$

滂 $31 \mathrm{~N}$

芳 $31 \mathrm{~N}$

娘 $31 \mathrm{~N}$

牀 $31 \mathrm{~N}$

明 $33 \mathrm{~W}$

精 $33 \mathrm{~W}$

清 $33 \mathrm{~W}$

影 $33 \mathrm{~W}$

並 $35 \mathrm{~W}$

定 $35 \mathrm{~W}$

不 $37 \mathrm{~N}$

透 $37 \mathrm{~N}$ 
心 $38 \mathrm{~N}$

審一 $(38 \mathrm{~N})$

匣一 $(40 \mathrm{~W})$

澄 $42 \mathrm{~N}$

When the list is rearranged in this way, we do note what appears to be a preference for certain YJ tables in making the graph selection, but this tendency is not particularly striking. If the list framer did select his graphs from the YJ in this way, he must have done so in a somewhat random fashion.

Now, let us sort the list yet again, this time according to whether the selected tables are nèizhuăn or wàizhuăn, and only then by table number:

$\mathrm{N}$ 奉 $2 \mathrm{~N}$

$\mathrm{N}$ 從 $2 \mathrm{~N}$

$\mathrm{N}$ 知 $4 \mathrm{~N}$

$\mathrm{N}$ 疑 $8 \mathrm{~N}$

$\mathrm{N}$ 微 $10 \mathrm{~N}$

$\mathrm{N}$ 非 $10 \mathrm{~N}$

喻一 $(11 \mathrm{~N})$

$\mathrm{N}$ 敷 $12 \mathrm{~N}$

$\mathrm{N}$ 邪 $29 \mathrm{~N}$

$\mathrm{N}$ 娘 $31 \mathrm{~N}$

$\mathrm{N}$ 幫 $31 \mathrm{~N}$

$\mathrm{N}$ 滂 $31 \mathrm{~N}$

$\mathrm{N}$ 牀 $31 \mathrm{~N}$

$\mathrm{N}$ 芳 $31 \mathrm{~N}$

$\mathrm{N}$ 不 $37 \mathrm{~N}$

$\mathrm{N}$ 透 $37 \mathrm{~N}$

$\mathrm{N}$ 心 $38 \mathrm{~N}$

審一 $(38 \mathrm{~N})$

$\mathrm{W}$ 來 $13 \mathrm{~W}$

$\mathrm{W}$ 泥 $13 \mathrm{~W}$

$\mathrm{W}$ 溪 $13 \mathrm{~W}$

$\mathrm{W}$ 日 $17 \mathrm{~W}$

$\mathrm{W}$ 群 $20 \mathrm{~W}$

$\mathrm{W}$ 徹 $23 \mathrm{~W}$

$\mathrm{W}$ 見 $23 \mathrm{~W}$

禪一 $(23 \mathrm{~W})$

W 穿 $24 \mathrm{~W}$

$\mathrm{W}$ 端 $24 \mathrm{~W}$ 
$\mathrm{W}$ 曉 $25 \mathrm{~W}$

$\mathrm{W}$ 照 $25 \mathrm{~W}$

$\mathrm{W}$ 影 $33 \mathrm{~W}$

$\mathrm{W}$ 明 $33 \mathrm{~W}$

W 清 $33 \mathrm{~W}$

W 精 $33 \mathrm{~W}$

$\mathrm{W}$ 並 $35 \mathrm{~W}$

$\mathrm{W}$ 定 $35 \mathrm{~W}$

匣一 $(40 \mathrm{~W})$

$\mathrm{N}$ 澄 $42 \mathrm{~N}$

Viewed in this way, the selected tables appear to form fairly cohesive "clusters" of identical, contiguous, or nearly contiguous members. And we need now to consider the possible implications of this configuration.

The designations nèizhuăn and wàizhuăn in the YJ have been of considerable interest to sinologists and sinolinguists and have been widely discussed in the secondary literature on the rime tables. To begin, it must be noted that the word zhuăn 轉 “turning” in these expressions has on the contrary not really received much attention in earlier treatments. It is rather the words nèi and wài that have interested earlier investigators. Our own view of the syllable zhuăn "turning" here is that it originally referred the turning through of a scroll during Buddhist liturgical and devotional recitation, a practice referred to in Chinese Buddhist parlance as zhuǎnjīng 轉經 "turning the sutra."4 In the rime tables, it was then adopted as a reference to a reading through (< "turning") of a table during the process of looking up syllables there (See Coblin 20o6b:147-148 for a more detailed discussion). A classic and rather influential early treatment of the nèi and wài concepts is Luo (1933). A more recent one is Norman (1988: 31-32). In our view, there are really three basic questions involved here. The first is of course what these designations mean in phonetic terms. The second, closely related to the first, is what the full semantic import of the names is. And the third, which has hitherto attracted relatively little scholarly attention, is why the designations nèizhuăn and wàizhuăn were placed in such a very prominent position at the absolute head of each YJ table.

The usually proposed answer to the first question is that nèi and wài correspond to fundamental qualities of vowels in the finals represented in the individual tables. And, not surprisingly, each researcher tends to find that the distinction turns out to support his own reconstructed medieval Chinese vowel values for the system inherent in the tables. The second question is consequently often answered by suggesting that nèi and wài are articulatory descriptions of the said vowel qualities. Norman, who, along with many others, agrees in general with Luo's conclusions about vowel quality, elaborates on this approach by suggesting that nèi and wài are Chinese translations of specific articulatory phonetic terms used by the Sanskrit grammarians. ${ }^{5}$ We remain agnostic regarding these ideas. It is rather the third question, not usually addressed by others, with which we intend to deal here.

4 In several major Chinese Buddhist sects the mere act of zhuănjīng is thought to accumulate karmic merit (jī gōngdé 積功德).

5 To wit: "It seems likely that these terms [i.e., nèi and wài; wsc] were taken from the Indian phonological terms äbhyantara 'internal' and bāhya 'external'; the first term refers to sounds that in some sense are produced within the mouth, and the second to sounds produced somewhere outside the mouth...As applied to vowels, the low vowel $a$ was 'external' because it was considered a neutral vowel in that it involved no special effort in the mouth..." (Norman, op. cit., p. 32). 
To begin, if the table "clusters" identified above are real entities rather than mere artifacts of our rearrangement of the table list, then this presupposes that whoever fashioned the rime table initial name list had at hand a rime table which was constructed differently from the earliest ones now known to us. To wit, in this early rime table prototype there would have been no initial names in the body of the table itself. This is in fact already true of the $\mathrm{YJ}$, where the 36 -initial name list is given in a synoptic chart in the prefatory matter of the text, rather than in the body of it. ${ }^{6}$ Furthermore, all nèi tables and all wài tables in the prototype would have been placed together in two large sets, i.e., nèi and wài sub-groups respectively. If this was indeed so, then we must suppose that at some later time the now lost prototype text was modified into the current YJ-type format of mixed nèi and wài tables. In this later arrangement the tables have been reordered so that the various QY rimes they comprise are roughly in the canonical order these rimes have in the QY/GY lineage of texts, almost certainly with the specific intent of replicating as much as possible this canonical QY ordering. We may then speculate that whoever made this change decided to indicate at the head of the tables he had reshuffled whether these tables had originally belonged to the nèi or wài sections of the prototype. This was perhaps done because he was reluctant to allow his recasting to efface completely all traces of the original format. Something rather like this did in fact happen when earlier hand-copied books were reset as block-printed texts in Sòng times. In such cases, the juàn 卷 numbers of the original scrolls of the books were often faithfully preserved in the printed versions, and then piously retained forever after.

These conjectures now bring us to the interesting matter of the original meaning of the terms nèi and wài in the tables. It is of course possible that they do refer to some articulatory aspect of the original pronunciation of the finals in the two groups. This cannot be rejected out of hand. However, an alternate possibility suggests itself. As mentioned above, before the advent of printing, Chinese books were written on scrolls. And a strategy for saving paper and reducing bulk was to write texts on both the recto and verso sides of these scrolls. Numerous examples of this have been found among the Chinese Dunhuang documents. Now, there are in the YJ altogether 43 tables. The following is a numbered list of these, with the nèi/wài distinction indicated for each:

$\begin{array}{lll}1 \mathrm{~N} & 16 \mathrm{~W} & 31 \mathrm{~N} \\ 2 \mathrm{~N} & 17 \mathrm{~W} & 32 \mathrm{~N} \\ 3 \mathrm{~W} & 18 \mathrm{~W} & 33 \mathrm{~W} \\ 4 \mathrm{~N} & 19 \mathrm{~W} & 34 \mathrm{~W} \\ 5 \mathrm{~N} & 20 \mathrm{~W} & 35 \mathrm{~W} \\ 6 \mathrm{~N} & 21 \mathrm{~W} & 36 \mathrm{~W} \\ 7 \mathrm{~N} & 22 \mathrm{~W} & 37 \mathrm{~N} \\ 8 \mathrm{~N} & 23 \mathrm{~W} & 38 \mathrm{~N} \\ 9 \mathrm{~N} & 24 \mathrm{~W} & 39 \mathrm{~W} \\ 10 \mathrm{~N} & 25 \mathrm{~W} & 40 \mathrm{~W} \\ 11 \mathrm{~N} & 26 \mathrm{~W} & 41 \mathrm{~W} \\ 12 \mathrm{~N} & 27 \mathrm{~N} & 42 \mathrm{~N} \\ 13 \mathrm{~W} & 28 \mathrm{~N} & 43 \mathrm{~N} \\ 14 \mathrm{~W} & 29 \mathrm{~N} & \\ 15 \mathrm{~W} & 30 \mathrm{~W} & \end{array}$

6 The initial class vertical columns in the YJ tables are identified by the well-known traditional-style descriptive nomenclature, i.e., qīng 清, cìqing 次清, zhuó 濁, etc. The 36 initial names do not appear there. The QYL does insert the canonical initial names into its individual tables. 
Let us now rearrange this list into two separate ones, with all the nèi tables in one sub-list and the wài tables in the other:

$\begin{array}{llll}1 \mathrm{~N} & 28 \mathrm{~N} & 3 \mathrm{~W} & 24 \mathrm{~W} \\ 2 \mathrm{~N} & 29 \mathrm{~N} & 13 \mathrm{~W} & 25 \mathrm{~W} \\ 4 \mathrm{~N} & 31 \mathrm{~N} & 14 \mathrm{~W} & 26 \mathrm{~W} \\ 5 \mathrm{~N} & 32 \mathrm{~N} & 15 \mathrm{~W} & 30 \mathrm{~W} \\ 6 \mathrm{~N} & 37 \mathrm{~N} & 16 \mathrm{~W} & 33 \mathrm{~W} \\ 7 \mathrm{~N} & 38 \mathrm{~N} & 17 \mathrm{~W} & 34 \mathrm{~W} \\ 8 \mathrm{~N} & 42 \mathrm{~N} & 18 \mathrm{~W} & 35 \mathrm{~W} \\ 9 \mathrm{~N} & 43 \mathrm{~N} & 19 \mathrm{~W} & 36 \mathrm{~W} \\ 10 \mathrm{~N} & & 20 \mathrm{~W} & 39 \mathrm{~W} \\ 11 \mathrm{~N} & & 21 \mathrm{~W} & 40 \mathrm{~W} \\ 12 \mathrm{~N} & & 22 \mathrm{~W} & 41 \mathrm{~W} \\ 27 \mathrm{~N} & & 23 \mathrm{~W} & \end{array}$

This would in fact have been a possible arrangement of our hypothetical pre-YJ prototype. It will now be noted that the nèi list contains exactly 20 tables, and the wài list 23. If this was indeed the layout of the prototype, then it would have been reasonable to copy the nèi group on the recto face of the scroll, and the wài group on the verso face. The amount of actual text material on each of the two faces would be nearly equal, and this arrangement would have had the advantage that the entire text would have been readily available on a single scroll. To view the nèi tables, one would unroll (i.e., "turn") the scroll and find them on the inside of it. The wài tables would, on the contrary, appear on the outside face of the scroll as it was unrolled. Could this possibly be the true origin of the words nèizhuăn "inner turning" and wàizhuăn "outer turning" in the rime table nomenclature? This idea is admittedly conjectural. But are the theories broached by others regarding the meaning of these terms any less so? Our theory is offered here as a fundamentally different alternative to these earlier ones. As a final observation, we should note that this theory does not preclude the possibility that the nèi and wài groups each comprised finals that were phonetically similar in some way. It merely proposes that the terms nèi and wài were not necessarily descriptive of any phonetic characteristics.

In summary, our suggestion regarding the question of the rime table initial names is that they were nearly all chosen from the token characters found in the cells of some ancestral rime table. It is also possible that the four that do not occur as such tokens in the YJ and QYL may actually have done so in the hypothesized prototype, and perhaps ultimately also in the hypothetical "Ur-Rime Table" itself. The choice of those tokens that serve as names was in a sense random, but it was nonetheless specifically limited to particular clusters of tables in the early prototype. Why the list-maker had recourse to these clusters, and not to others, remains uncertain.

\section{Acknowledgement}

My thanks to Professors Ting Pang-Hsin and Newell Ann Van Auken for reading and commenting on an earlier version of this paper. All remaining weaknesses are entirely my own. 


\section{References}

Bottéro, Françoise. 2013. The Qièyùn manuscripts from Dūnhuáng. Studies in Chinese Manuscripts: From the Warring States Period to the 2oth Century, ed. by Imre Galambos. Budapest Monographs in East Asian Studies, 33-48. Budapest: Institute of East Asian Studies, Eötvös Loránd University.

Coblin, W. South. 2006a. Reflections on the Shouwen fragments. The Chinese Rime Tables-Linguistic Philosophy and Historical-Comparative Phonology, ed. by David P. Branner, 99-122. Amsterdam and Philadelphia: John Benjamins.

Coblin, W. South. 2006b. Zhang Linzhi on the Yunjing. The Chinese Rime Tables-Linguistic Philosophy and Historical-Comparative Phonology, ed. by David P. Branner, 123-149. Amsterdam and Philadelphia: John Benjamins.

Liu, Fu. 劉復.1968. 《十韻彙編》。台北：學生書局。

Long, Yuchun. 龍宇純. 1968. 《唐寫全本王仁昫刊謬補缺切韻校箋》。香港：香港中文大學出版社。

Luo, Changpei. 羅常培. 1933. 釋內外轉. 《歷史語言研究所集刊》4.2: 209-226. (Repr. in Luo (1963): 87-101).

Luo, Changpei. 羅常培. 1963. 《羅常培語言學論文選集》。北京：中華書局。

Norman, Jerry L. 1988. Chinese. Cambridge: Cambridge University Press.

Zhou, Zumo. 周祖謨. 1960. 《廣韻校本》，(重印於1988)。北京：中華書局。 


\title{
“三十六字母” 傳統名目的由來
}

\author{
柯蔚南 \\ 愛荷華大學 \\ south-coblin@uiowa.edu
}

\section{摘要}

“三十六字母” 是等韻圖結構的基本成份, 因而向來也是傳統聲韻學家的重要研究對象。歷史語言學家著重於兩 項, 其一就是 “字母” 在切韻系統裡所代表的組成單位, 其二是這些單位在古漢語聲母系列裡的實際音值。這兩項 題目毫無疑問是關鍵問題。此外一個細小而引人好奇之謎, 如各 “字母” 本身的傳統名目來自何處, 是怎麼樣取的 或者創造的, 本文擬解開這個小謎。

\section{關鍵詞}

韻圖、韻書、漢語語文學傳統、歷史音韻學 